\title{
The Spanish Labor Universities and the Belgian Labor University: An Example of Education Transfer and Transformation (1955-1983)
}

\section{Carmen Sanchidrián Blanco}

University of Málaga

\section{María Dolores Molina Poveda}

University of Málaga

\begin{abstract}
The Falange of José Antonio Primo de Rivera and the Franco regime imported from other countries several institutions, among them, the Labour Universities (1955-1983). José Antonio Girón was the founder, although to create them he followed the Belgian Labor University (1911) created by Paul Pastur. In this paper, we will analyze the similarities and differences between both institutions through the information that NODO (Noticiarios-Documentales) (Newsreels and Documentaries, audiovisual propaganda of Franco's regime) offered in its newsreels about the Spanish Labour Universities. Both institutions were similar in the architecture, in the design of spaces, and in offering different specialties, mainly in the industrial field. They differed in the context in which they were born. The Belgian Labor University was also imported into other countries such as France, Zaire, Montevideo, Iran and China.
\end{abstract}

Keywords: labor universities, propaganda, Francoism, NO-DO, Belgian Labor University

ISSN 2560-8371

DOI: 10.24908/encounters.v21i0.14084

(C) Encounters in Theory and History of Education | 113 


\section{Les Universités du Travail espagnoles et l'Université du Travail Belge : Un exemple de transfert et de transformation éducative (1955-1983)}

\section{Résumé}

La Falange de José Antonio Primo de Rivera et le franquisme ont importé d'autres pays plusieurs institutions parmi lesquelles se trouvent les Universités du Travail (19551983). José Antonio Girón a été le fondateur, bien que pour les créer, il a suivi I'Université du Travail belge (1911) créé par Paul Pastur. Dans cet article, nous analyserons les similitudes et les différences entre les deux institutions à travers les informations que NO-DO (Noticiarios-Documentales) (Actualités et documentaires, propagande audiovisuelle du régime de Franco) a offert dans ses numéros sur les universités du travail espagnoles. Les deux institutions partagent des modèles architecturaux similaires et une gamme similaire de spécialités, principalement dans le domaine industriel. Elles diffèrent dans le contexte dans lequel elles sont nées. L'Université du Travail belge a été importée dans d'autres pays comme la France, le Zaïre, Montevideo, Iran et la Chine.

Mots-clés: universidades laborales, propagande, Franquisme, NO-DO, Université Belge du Travail

\section{Las Universidades Laborales españolas y la Universidad del Trabajo Belga: Un ejemplo de transferencia y transformación educativa (1955- 1983)}

\section{Resumen}

Tanto la Falange de José Antonio Primo de Rivera como el franquismo importaron de otros países varias instituciones entre las que destacan las Universidades Laborales (1955-1983). José Antonio Girón fue su fundador y para crearlas se basó en la Universidad del Trabajo (1911) belga fundada por Paul Pastur. En el presente trabajo analizaremos las semejanzas y diferencias entre ambas instituciones a través de la información que NO-DO (NOticiarios-DOcumentales) (medio propagandístico audiovisual del régimen franquista) aportó en sus números cinematográficos sobre las Universidades Laborales españolas. Ambas instituciones se asemejaban en la arquitectura y diseño de los espacios, y en las especialidades que ofertaban, sobre todo industriales, y diferían en el contexto en el que nacieron. La Universidad belga del Trabajo también fue importada por otros países como Francia, Zaire, Montevideo, Irán y China. 
Palabras clave: universidades laborales, propaganda, Franquismo, NO-DO, Universidad Belga del Trabajo

\section{Introduction}

Nowadays, national education systems worldwide are connected and are interdependent. Although these processes of change developed faster after the second world war, it is possible to find examples of cross-cultural transfers at any time in history. Most of the theories, methods or institutions were adopted and then adapted, as it is the case of the Spanish Labor Universities.

It is a well-known fact that the Falange and Franco's regime imported a variety of institutions and activities from other countries, mainly from Germany and Italy. Some of them are well known and have been the object of several studies, such as the Auxilio de Invierno (Winter Aid), a literal translation of its German equivalent Winterhilfe, which was later renamed Auxilio Social (Social Aid) (Cenarro Lagunas, 2005, 2009; González de Tena, 2009). Another import were some of the programs of the Bund Deutscher Mädel (BDM, German Girls' Union) which, in 1937 took several groups of the Women's Section to Germany to learn about leadership schools, training for women, the importance of contact with nature, the discipline of the BDM and the National Labor Service for Young Women (Dueñas Cepeda, 2010; Morant i Ariño, 2013). However, there were also later and less known "imports" such as the Labor Universities (hereafter LUs) which were inspired by the Belgian Labor University (Université $d u$ Travail, hereafter UT).

The post-war, that is the entire decade of the 1940s, was one of the most repressive and darkest periods of Spain's recent history. The casualties caused by the war and the repression, together with the amount of people in exile and in prison because of their antiregime ideas, meant a great loss of human capital that prevented Spain from returning to normality and the swift rebuilding of the country. Furthermore, the political and cultural isolation the country was subjected to because of the dictatorship, plus the Second World War, forced Franco to implement several measures which certainly didn't help neither Spanish economy and industry, nor its opening up to the outside world. García Delgado and Jiménez (2007) highlight three peculiar aspects to Franco's economy of those years: a strong interventionism, autarchy (the States's attempt to be self-sufficient with the country's internal production) and inflationary pressure.

The isolation, autarchy and inflationary pressure that Spain was subjected to during the post-war period meant that the previous industrial development came to a halt or declined so that the industry no longer required highly qualified workers. However, the 1950s saw the start of a new era called "hinge decade", a term adopted by García Delgado (2003) to refer to the transition between the period of hardship Spain endured 
in the 1940s and the big changes and advances that began in the 1960s. This period was characterized by improvements in consumption, a rise in per capita income, a relative deregulation of the economy, the elimination of rationing, commercial exchanges with foreign countries, the modernization of the production sector, the recovery and expansion of the industry, entry into foreign organisations (UN, FAO, UNESCO, WHO, Postal Union, World Bank, IMF and OEEC) which had up to then banned the Spanish State (Yllán Calderón, 2016). All in all, it was a time of opening and development that led to the establishment of a string of actions to boost the industry and, as a result, to the return of Vocational Training, which, during the post-war period, had been the least addressed level of education. The impulse given to Vocational Training came about because people who had emigrated after the war to rural areas returned to the industrial areas and to the big cities and found that they lacked the necessary knowledge to be able to work (Bascuñán, 1999).

Given this situation, the Labor Colleges were created. On 16 July 1949, the Foundation Law on Secondary and Vocational Education (Ley de Bases de Enseñanza Media y Profesional) was passed, creating the Labour/Technical Baccalaureate. The State and the Ministry of National Education developed this branch of Secondary School to try to avoid the loss of "useful intelligence" of the people who were based in rural, industrial or coastal places far from the provincial capitals or major cities; the need to establish a mixed education system where human and technical professional training was catered for; the necessity of offering youngsters some elementary studies comparable to the first courses of the University Baccalaureate, supplemented by education that would enable them to learn a trade; and the idea of offering students two paths so that they could decide whether to continue with higher/university studies or to be trained in "modern" vocational education (Law of 16 July 1949, preamble).

The subjects that were taught in Labor Colleges - which could be for males or females, state or private - were agriculture and livestock, industry and mining, maritime, female occupations and, from 1958, administration. Basically, these centres were created with the idea of modernising this educational level by going a little further than the Basic School of Work and the Schools of Arts and Crafts that were at a standstill in terms of student numbers. These colleges, which were part of Secondary Education, were used by the Minister of Labor, José Antonio Girón de Velasco, to promote LUs as the highest level of Vocational Training. This institution was modelled on the École Industrielle Supérieure of Charleroi (Belgium), founded by Paul Pastur (1866-1938) in 1903, which became the UT in 1911.

Spain was not the only country that looked to the Belgian UT to create a Vocational Training institution, as other countries such as France, Zaire, Montevideo and Teheran also drew inspiration from this Belgian college to set up their own schools which they adapted to their own situation. One of them was China, a country geographically and culturally far from Belgium and Spain, which took the UT as a model to create Shanghai's National Labor University, which operated from 1927 to 1932, that is, 
before Spanish LUs (Chan \& Dirlik, 1991). This study aims at finding out, fundamentally through what NO-DO (News and Documentaries) showed about the Spanish institutions, what was imported to Spain from the Belgium UT.

\section{Newsreels and Documentaries, "NO-DO"}

The New State needed to "become a well-oiled machine ready to carry out a fundamental task: justify its own existence to the public" (Martín de la Guardia, 2006, p. 15). The press, both written and audio-visual, was its main ally to make society believe that the new politics was the right one. The new regime placed a bet and won, as it managed to stay in power by using this propaganda network to infiltrate into the life of all Spaniards and repress them to such an extent that they had to accept everything they were told without opposition and had to openly show their support. This was also due to the fact that what was left the country so depleted and impoverished that the survivors had no choice. Out of all the propaganda, information and communication promoted by the Franco regime, we are going to focus on the cinematographic News and Documentaries, known as "NO-DO" (Noticiarios y Documentales cinematográficos), as it was one of the channels through which the new regime recorded a great variety of news, some of them related to LUs.

This organization was created at the end of 1942 and depended on the Deputy Secretary of Popular Education. According to Joaquín Soriano - the first director of NO-DO-, this institution was born with the aim of "being as good as the best, enjoyable, instructive, varied and technically perfect", and of reaching "the furthest corner of our country in the shortest time" reflecting "all the noble aspects of the life of our nation: political, economic, artistic, cultural, scientific, sports, etc. It also sought to show the same facets, whenever possible, worldwide. To sum it up, it had to inform, instruct and recreate" (1942, p. 7), in line with its slogan of putting "the whole world within the reach of all Spaniards." This cinematographic resource was conceived "for hardly literate people with almost no travel culture and designed for its distribution at the star show of social entertainment: the cinema" (Sánchez-Biosca, 2009, p. 3). In the news, therefore, "curiosities, attractions, events, fashion, nature, sports, disasters [were] more important than political information" (Sánchez-Biosca, 2009, p. 3).

After the Civil War, the access that people had to information was determined by their economic and education level and, sometimes, by their political views (Rodríguez Mateos, 2008). According to Sevillano Calero (1998), the people who had better access to the press and radio in the 1940s were the wealthiest and most highly educated, while the lower social classes were not so well informed. In other words, the media had an "indirect and ambivalent impact" (Sevillano Calero, 2000, p. 38) due to unequal access to information, mistrust of official information and dissonance between people's daily life and propaganda messages. NO-DO was born in this context as a 
mean of popular education of "citizens whose education level does not go beyond elementary school" (Rodríguez Martínez, 1999, p. 10). This resource was made up of images and spoken words, two features which made it a great tool for the population's education and training as its content was understood by everyone regardless of whether they could read or write. Rodríguez Mateos (2008) points out that NO-DO was probably "the tool with the greatest capacity for social penetration. As it was compulsory to show it in the country's cinemas", so that "all viewers saw it or had the chance to see it" regardless of their literacy level (p. 32). In short, NO-DO newsreels and documentaries enjoyed "great popularity since in those years the cinema was an important form of entertainment" (Rodríguez Mateos, 2008, p. 32), although some authors claim that it hardly had any real influence. Its propaganda, they argue, was so obvious that no one could really be convinced by its contents (Paz, 2003, p. 357).

The cinematographic newsreels NO-DO were initially called filmed press, and from 1968 they became known as a cinematographic magazine. It was compulsory to show the newsreels at cinemas throughout the week and NO-DO had the production monopoly in this area, even though, due to the shortage of copies and the distribution and exhibition network established for the entire Spanish territory, some cinemas screened these newsreels with delays (news items were sometimes broadcast weeks or months after they had taken place). In spite of this, NO-DO's cinema news was the main audiovisual propaganda weapon of the regime and the best known newscast amongst Spaniards. Furthermore, the News were NO-DO's main product as it was the first one to be produced, the one that lasted the longest (from 1943 to 1981 with a total of 4016 releases), because of its frequency and compulsory screening in all cinemas before the start of the film. However, this study will also focus on other NO-DO's products such as the Black and White Documentaries (Documentales en blanco $y$ negro), Color Documentaries (Documentales en color) ${ }^{1}$ and Image Magazine (Revista de imágenes) ${ }^{2}$ as they showed images of LUs. NO-DO broadcast 25 pieces of news and documentaries on this topic, out of which 14 were made for the Newsreels section, 5 for Image Magazine and 6 for the Black and White Documentaries. No documentary was produced on this topic in the Color Documentary section.

The information broadcast about LUs by NO-DO's newsreels, documentaries and reports has been contrasted with secondary sources for both the LUs, and for the Belgiam UT. Since our study focuses on what was showed by NO-DO on the Spanish LUs and on its similarities and differences with the Belgian institution, we have not used primary sources for the UT. The selection of news, documentaries and reports about these universities was carried out as follows: by viewing all the NO-DOs indexed on Filmoteca Española, which is located on the RTVE website; by searching for key words in the website's search engine and by comparing them with the releases found in the first item; the information was then extracted from each release by using an observation form. ${ }^{3}$ The main topics addressed by NO-DO on this issue were 
inaugurations, visits from authorities, and information about how they worked, architectural features, etc., of one of the regime's most emblematic projects.

\section{Labor Universities through NO-DO: Similarities and Differences with the Belgian Labor University}

With the creation of the Labor Baccalaureate and the Labor Colleges, secondary education, which had previously been restricted to the privileged classes and mainly oriented to the University, was extended to the working classes. Sánchez Sánchez (2006) claims that the creation of the Labor Baccalaureate was used by the then Minister of Labor, José Antonio Girón de Velasco, to launch a project aimed at bringing the University closer to the underprivileged classes. The history of Labor Universities can be divided into three stages: creation (up to 1962), consolidation and normative stabilization (1957-1962) and expansion (until they disappeared). Brunet and Moral (2017) state that

The period of economic boom and expansion led the labor administration, with the participation of some large companies, to opt for a vocational training program aimed mainly at those who came from rural areas, who were redirected towards industrial towns that needed a large number of workers during the decade of Franco's developmentalism. (p. 96)

The LUs project promoted by Girón took its institutional and architectural inspiration from the Higher Industrial School of Charleroi (Belgium), therefore both institutions showed similarities, albeit also had notable differences. Charleroi is today the most populated town in the Walloon region and its history is linked to coal mining and the metallurgical industry of the $19^{\text {th }}$ century, although most of its industries closed down from the 1950s onwards. The similarities were not only architectural and institutional, their creation stemmed from the similar situation that inspired their founders and in the social initiatives they implemented - Paul Pastur was assisted by Alfred Langlois, a military man, and José Antonio Girón by Juan Yagüe, a Falangist general-, and in their professional careers (both studied law). Paul Pastur (1866-1938), a socialist deputy in Hainaut province, founded the Ecole Industrielle Supérieure, which would become the UT in 1911, to "improve the technical and human training of the miners of the Hainaut province from an intellectual, technical, social, moral, physical, artistic and aesthetic perspective" (Delgado Granados, 2012, p. 89-90).

This centre, which aimed at the "social advancement of workers without resources" (Robles Cardona, 2014, p. 30), was created after the mining revolutions of 1886, a time that remained engraved in the collective memory as the "terrible year" in Belgium. The workers' upheavals and strikes began with a rally on March $18^{\text {th }}$ in Liege, which brutally demonstrated the "social question" behind intense industrial development: "The 
district of Charleroi, which had already known a population growth of $22.50 \%$ in 1816 , kept developing and, between 1846 and $1880,40 \%$ of the nearby towns increased their population by more than $100 \%$ " (Velasco, 2004, p. 211). A state of siege was declared, the army intervened, and the repression was very harsh. In the medium and long term, these events had significant social repercussions. The government commissioned a survey to ascertain the working conditions of labourers, as a result of which social legislation began to emerge: in 1889, work was banned for children under 12 and women under 21; night work was also banned and a 12-hour limit on the working day was established. In this context, the Belgian Workers' Party (founded in 1885) established itself as a mass workers' party (Velasco, 2004). Pastur was the leader of this party and always fought for universal suffrage and for legislations that would improve the lives of the workers, especially after the events experienced on the Sambre-Meuse axis (where Charleroi is located) which had an impact on his life and prompted him to work for social actions that would improve the miners' situation. Pastur was a councillor in Charleroi between 1896 and 1900 and only accepted provincial assignments between 1900 and 1938 when he was a permanent deputy in Hainaut (a province belonging to Charleroi).

Pastur worked mainly to make education more democratic and promote the emancipation of people. Because of his social interests, in 1903 he planned the creation of a provincial Superior Industrial School that would later become the UT in 1911. This coincided with the International Exhibition in Charleroi. The aim of this exhibition was to show visitors the achievements of a region that was at the forefront of the industrial revolution and where the UT was shown as an instrument to train the qualified workforce needed by an expanding industry (VV.AA., 2011). In this sense, the objectives of Labor Universities in Belgium and Spain were similar: training a qualified labour force. However, Pastur started from a socialist approach while Girón had a Falangist approach. However, the aesthetics of the ads at the time was similar (see Image 1). 

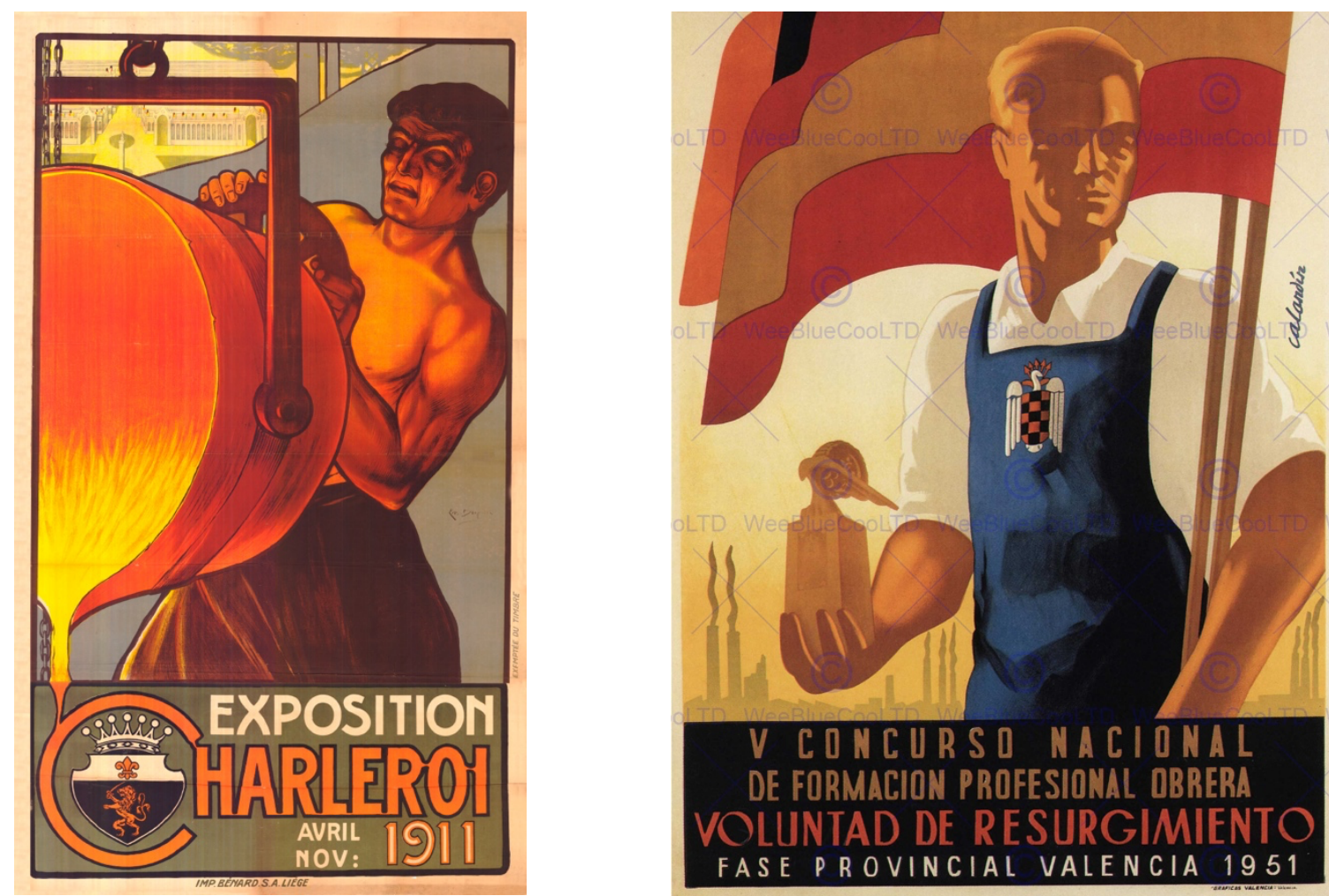

Image 1: Advertisements of the exhibition held in Charleroi in 1911 and of the National Competition for Vocational Training for Workers held in Valencia in 1951. Sources: https://bit.ly/3b9Ksm7 and https://bit.ly/2WkibFv.

Between 1941 and 1957 José Antonio Girón, Minister of Labor, implemented a series of social measures - Health insurance, the Institute of Medicine, Hygiene and Safety at Work and legislation on social housing, which resulted in entire neighborhoods being built with this type of housing in the largest cities- where LUs were founded, with Gijón's being the first one. At first, the building designed by Girón was to house an orphanage for children of mining parents, which shows Girón's concern for the mining cause. This is perhaps because he came from the province of Palencia and because of the serious accidents that occurred in mines in the 1940s, such as the one in Pozo Calero (Palencia) in April 1941 or the one in Saldes (Barcelona) in 1944, with 18 and 34 deaths, respectively. However, from 1948 this project was changed and adapted to the needs of LUs. Giron's work continued to develop and grow during the 1950s, and in 1956 the Labor Universities of Gijón, Zamora, Tarragona, Seville and Córdoba came into operation (Delgado Granados, 2005a).

Delgado-Granados and Ramírez-Macías (2017) highlight that the statistics on education from the National Statistics Institute (INE, Instituto Nacional de Estadística) (1939-1949) showed a very slow growth of vocational training in contrast to secondary education: the Basic Schools of Work had grown only in 1578 students, and the Schools of Arts and Crafts in 7423, reaching a total of 9000 , while there were 58913 students in secondary education. However, this panorama changed with the 
enactment of the Industrial Vocational Training Act of 1955, which "supposed [...] the consolidation of regulated vocational training studies" (Delgado-Granados and Ramírez-Macías, 2017, p. 125) and recognized, for the first time and legally, these new institutions (Martínez Usarralde, 2002). This consolidation was also due to the end of the autarchy and the opening of Spain to international trade and needed foreign investment that drove the growth of the industry along with the Act 40/1959 of May 11 and the Regulations approved by Decree 2265/1960 of November 24, 1960.

The LUs were institutionally dependent on the Ministry of Labor, which was responsible for their supervision, and the Ministry of National Education, which was responsible for strictly curricular aspects and their inspection (Delgado Granados, 2012). Although the 1955 Act was not fully implemented (the 1958 plan kept only two stages, apprenticeship and master's degree instead of the four planned in 1955), in its preamble it stated that "far from hindering with repetitive tests the possibility for young workers to reach the highest degree of vocational training or the corresponding intermediate and higher technical studies, this change is provided to those who deserve it because of their skills and knowledge". It is recognized as an ambitious law ahead of its time (Martínez Usarralde, 2015).

The aim of LUs was to train industrial and agricultural workers and apply "Falangist social justice" under the imperatives of "justice and efficiency" (Delgado Granados, 2005b, pp. 62-63). The term "justice" referred to the opportunities that the regime offered to families by providing their children with vocational training and early employment that would prevent the economic decline of the family, as well as a culturalization that would avert the social revolutions generated by ignorance and, as a consequence, by class hatred (Zafrilla, 1999). "Effectiveness" referred to the fact that, by implementing the school boarding system, the young interns were encouraged to leave the family home and were introduced to a study environment and to the ideological principles of the system.

In NO-DO, which never mentions the Belgian institution, LUs were promoted by defining them as "genuine works of peace and justice" (Documental en Blanco y Negro, Veinte años de paz [Twenty years of peace], 01/01/1959) "with a deep Christian and social meaning" (Noticiario n. $\left.{ }^{\circ} 724 \mathrm{~A}, 19 / 11 / 1956\right)$ in which thousands of Spaniards who previously did not have access to them would receive "technical teachings" (Documental en Blanco y Negro, Veinte años de paz [Twenty years of peace], 01/01/1959) and which would "prepare young people for the massive development that the country [demanded]" (Documental en Blanco y Negro, Ha visto usted España [You have seen Spain], 01/01/1963). Labor Universities, according to the commentator of the Noticiario n. ${ }^{\circ} 526 \mathrm{~A}$ (02/02/1953), were defined as "an important milestone in the spreading of culture among the economically weak" in which "one of the fundamental aims of the regime was fulfilled: the improvement of our culture".

In 1957, a new government was formed that marked the transition from the autarchic model to the authoritarian-technocratic one. The Minister of National 
Education, Jesús Rubio García (1957-1962), remained in office, while the Minister of Labor, José Antonio Girón, stepped down and was replaced by Fermín Sanz-Orrio (1957-1962). This change stopped the construction of new Labor Universities that were left without the support of their founder, as the new minister focused on the stabilization of the existing universities through the enactment of a series of legislative measures that repealed the provisional Statute of 1956 (Delgado Granados, 2010). In 1958 the first Teaching Statute of Labor Universities was enacted, but the intended stabilization was not achieved until the enactment of the Law of 11 May 1959 on Labor Universities and Decree 2265/1960 of 24 November, which approved the rules and regulations of these centres. Article 4 of the Decree of 1960 established that the education offered at the Labor Universities was divided into two groups: regulated education (Industrial and Agricultural Vocational Training, Elementary and Higher Labor Baccalaureate, Intermediate and Higher Technical Training, Human and Social Training and others that were introduced after the above-mentioned legislation) and nonregulated education (training of specialised technicians to cover production needs, professional development and social training). Faced with the social upheavals of the 1960s, Franco reorganized his ministerial team by putting Jesús Romeo Gorría (19621969) at the head of the Ministry of Labor. Romeo began a new phase where the building of Labor Universities was resumed and continued in the seventies: La Coruña (1964), Alcalá de Henares (1966), Huesca, Zaragoza and Cáceres (1967), Éibar (1968), Cheste (1969), La Laguna, Las Palmas and Toledo (1972), Málaga (1973), Almería and Logroño (1974), Albacete and Orense (1975) and Vigo (1976).

In two reports shown by NO-DO in the section Revista de Imágenes, special emphasis was placed on the fact that LUs were created because of the huge need for labor. An example given by one of these reports (Revista de Imágenes, Nuevos hogares [New homes], 01/01/1965) was the need for specialized builders due to the new plans promoted by the State. As a consequence, as the narrator of one of the editions explained, Vocational Training centres multiplied, and Labor Universities were created where students took "courses of different degrees and specialisations" (Revista de Imágenes, Nuevos hogares [New Homes], 01/01/1965). "In Labor Universities and Professional Training Centers the training of specialized workers is taking place that will open the future to us" (Revista de Imágenes, Veinticinco años de paz en la cultura Española [Twenty-five years of peace in the Spanish Culture], 01/01/1964). The presenter of Revista de Imágenes n. ${ }^{\circ} 717$ (01/01/1958) defined LUs as "one of the most beautiful and revolutionary Spanish enterprises that, based on the imperative of justice, [claimed] on behalf of producers the improvement of intelligence and the profession, and the dignity of work". Students who enrolled in these centres could study specialized industrial, agricultural (see Image 2) and maritime-fishing trades according to their vocation and aptitude, while they received physical and gymnastic instruction. Moreover, the most talented ones could have access to higher technical studies. 


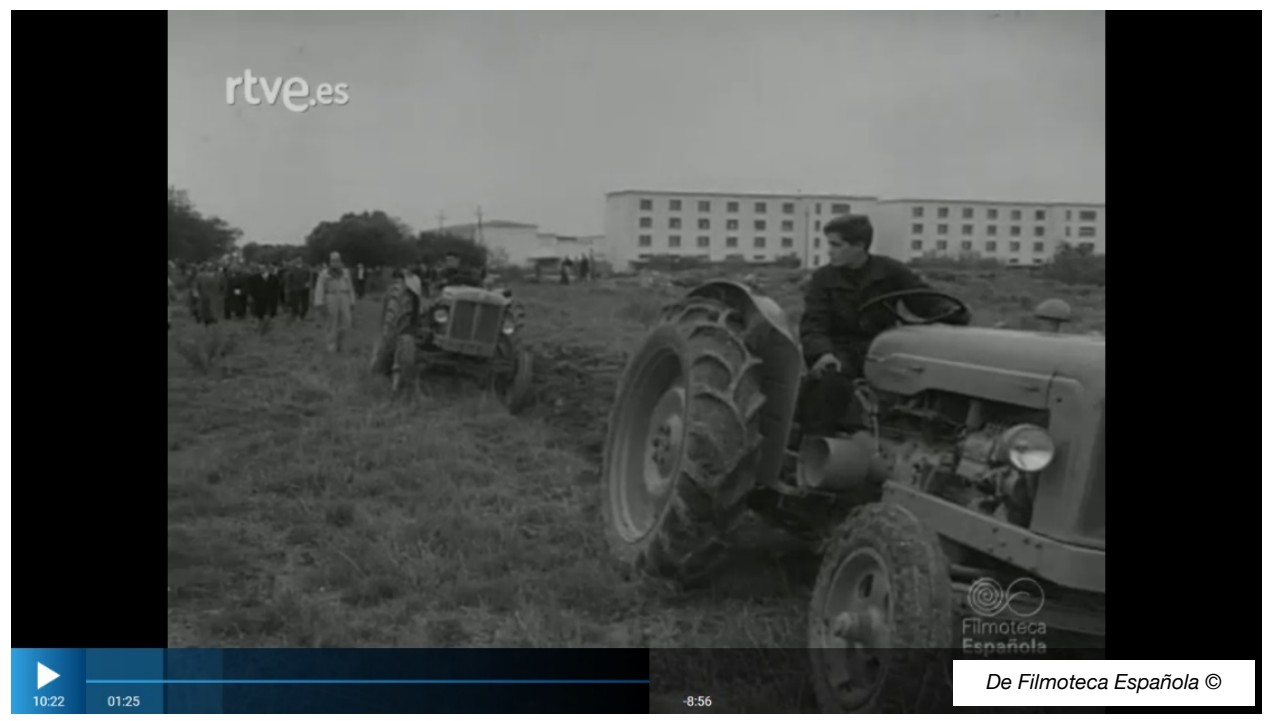

Image 2: Students from the Francisco Franco Labor University in Tarragona in a tractor driver training course. Source: Noticiario n. ${ }^{\circ} 832 \mathrm{~A}(15 / 12 / 1958)$.

As previously mentioned, the Belgian institution and the Spanish LUs were created to help young people with scarce resources train and find $a$ jo $b$ that would allow them to integrate into the industrial society of the time. However, Díaz González (2017) points out that the Belgian centre was founded as an open, democratic and secular initiative, while the Spanish institutions were created in a dictatorial and religious context in which most of the LUs were managed and run by religious orders. ${ }^{4}$

These centers were created with the aim of "achieving a significant social advance so that, regardless of their financial possibilities, everyone in Spain [had] sufficient technical and scientific training, and [obtained] the corresponding qualification" (Documental en Blanco y Negro, Resumen de la Actualidad Española [Summary of Spanish News], 1956, 01/01/1957). To achieve this objective, large centres were needed that could house and instruct as many students -both boarders and day students- as possible. Spanish LUs took inspiration from the architecture of the Belgian UT, since it was designed "as a set of enormous and avant-garde buildings, with spacious classrooms and workshops specialized in the different professional fields that were on offer. This is where students will receive their full education" (Robles Cardona, 2014, p. 31).

Delgado-Granados and Ramírez-Macías (2017) confirm that the UT stood out "for its titanic and avant-garde elements, forming a set of buildings with spacious classrooms and specialized workshops, according to the different professional specialties". The Belgian UT became over time "one of the most important European educational references, given its innovative character, and was exported to France, [...] and later to Spain, with the Labor Universities" (p. 124). 
NO-DO was a faithful reflection of these great buildings that would house the Spanish Labor Universities. Although the Belgian UT never appeared, the great similarities can be appreciated in image 3 (buildings) and image 4 (workshops).
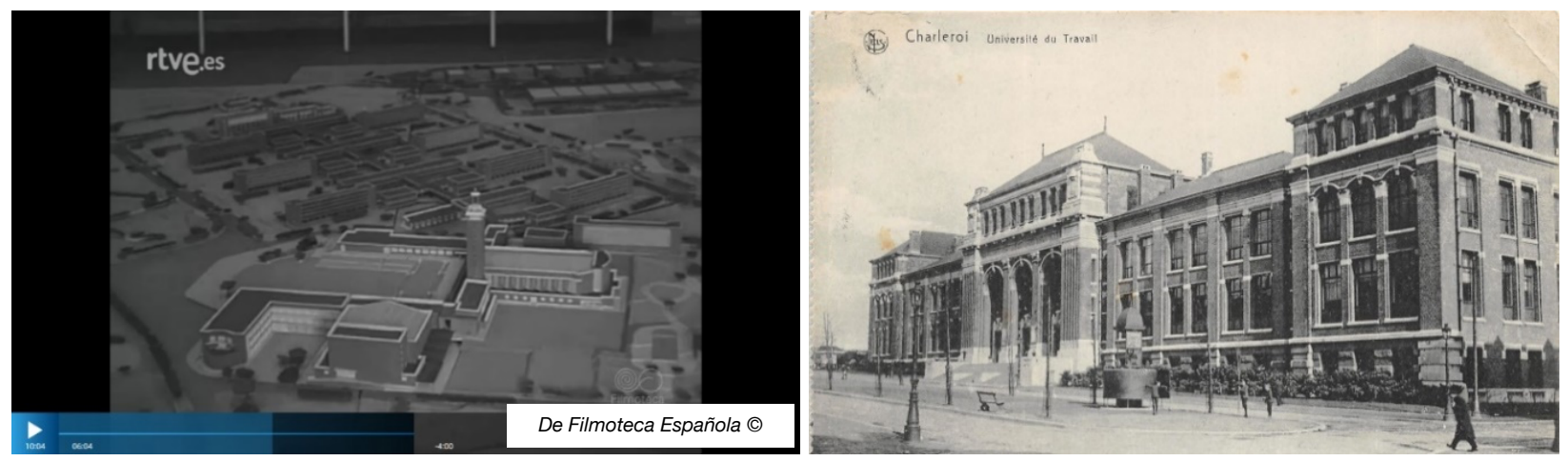

Image 3: Model of the José Antonio Primo de Rivera Labor University (Seville) and main facade of the Belgian UT. Source: Noticiario n. ${ }^{\circ} 695 \mathrm{~A}(30 / 04 / 1956)$ and Postcard retrieved from https://www.geneanet.org/cartes-postales/view/7696651\#0.
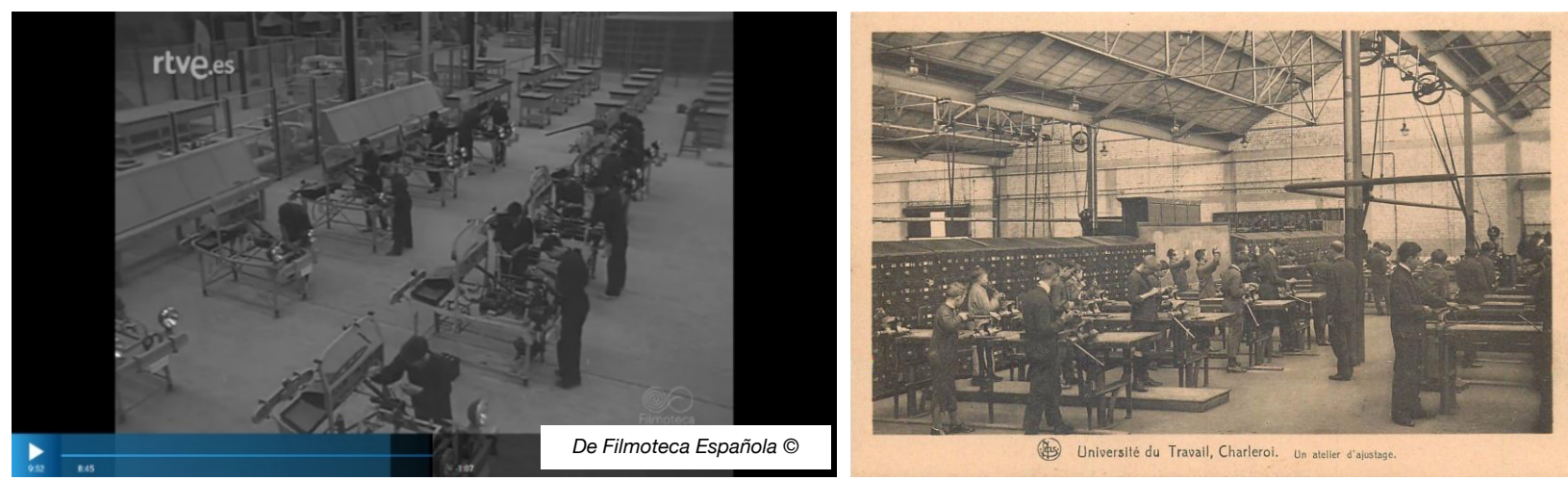

Image 4: Students in workshops (Francisco Franco Labor University in Tarragona and UT). Source: Revista de Imágenes n. 717 (01/01/1958) and Postcard retrieved from https://www.hippostcard.com/listing/belgium-belgique-universite-du-travail-charleroi-atelier-dajustage/21478567.

The voice-over of the Noticiario $n .^{\circ} 567 A(16 / 11 / 1953)$ explained that the Labor University of Zamora ${ }^{5}$ had a capacity for more than 600 external and 300 boarding children and had "workshops for carpentry, printing, tailoring, shoemaking, forging and mechanics with modern machinery". In Noticiario n. ${ }^{\circ} 695$ A (30/04/1956) the presenter reported that the José Antonio Primo de Rivera Labor University (Seville) covered a total of 1,078 square meters, was shaped like a fishbone and had a capacity of 6,000 students, although only 500 young people were enrolled in its first year (Documental en Blanco y Negro, Resumen de la Actualidad Española [Summary of Spanish News], 1956, 01/01/1957). The Onésimo Redondo Labor University in Córdoba occupied an area of four million square meters, comprised of six buildings in a cross and each building was a school (Noticiario n. $\left.{ }^{\circ} 724 \mathrm{~A}, 19 / 11 / 1959\right)$ (see Image 5). During its first 
year it hosted just 560 students, although this number increased to 1,370 five years after its opening. The Labor University of Zaragoza had a capacity for 4,000 students, although in its first year only 650 boys were enrolled (Noticiario n. ${ }^{\circ} 724 \mathrm{~B}, 19 / 11 / 1956$ ).

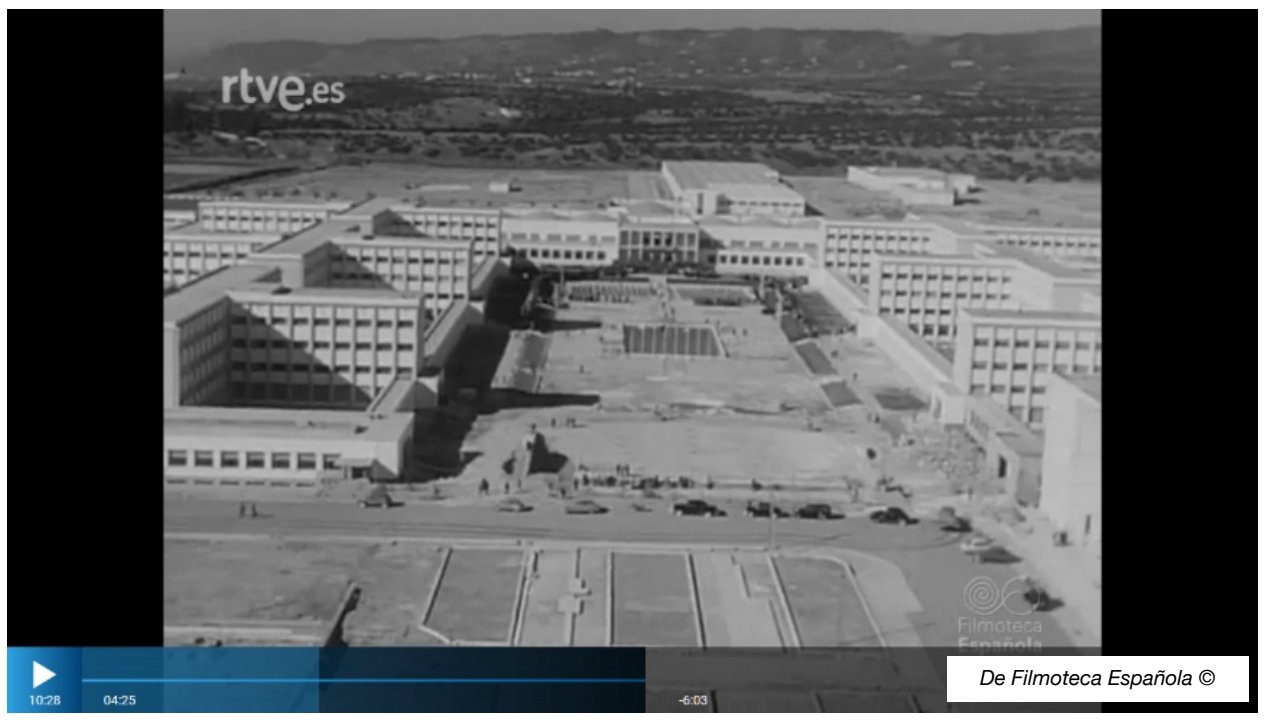

Image 5: Onésimo Redondo Labor University (Córdoba). Source: Noticiario n. 724A (19/11/1956).

The Marítimo-Pesquera Labor University in La Coruña occupied an area of 20,000 square metres (Noticiario n. $\left.{ }^{\circ} 1024 \mathrm{~A}, 20 / 08 / 1962\right)$. The Labor University of Alcalá de Henares could accommodate up to 5,000 students, although in its first year only 1,517 young people enrolled, since, according to the narrator, "it did not seem prudent to put it at one hundred percent of its possibilities"(Revista de Imágenes, El camino de la plata [The Silver Route], 01/01/1967). TheLU of Gijón occupied three million square meters (270.000 square metres built). These macro-institutions were built to house a large number of students of both regulated and non-regulated technical-manual studies (these studies were divided into three sections: Vocational Training and Technical Training, Social Training and Professional Improvement and Human Training). Then, they were designed so that "they would work [...] with the same programs as their homonyms in the rest of Spain, with special interest in political, sports, social and humanistic training" (Delgado-Granados and Ramírez Macías, 2017, p. 128). 


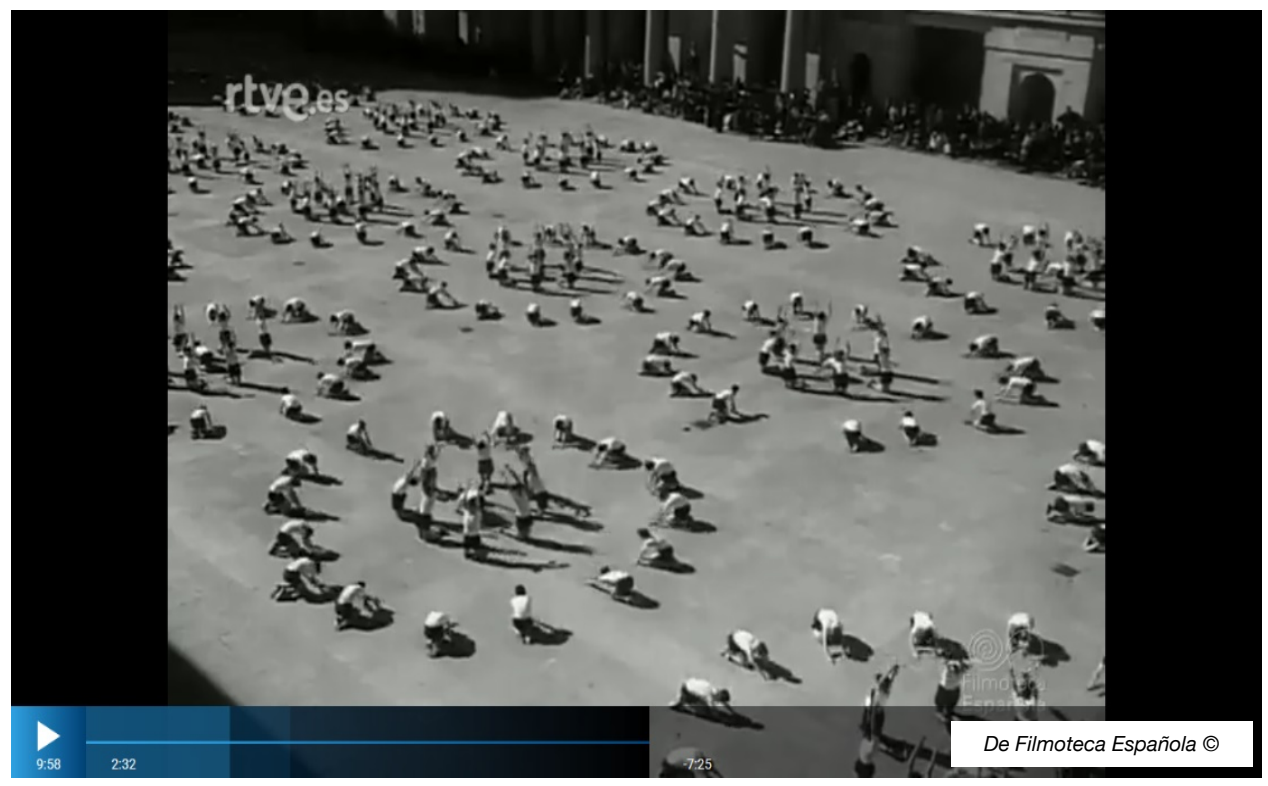

Image 6: Students from the José Antonio Girón Labor University of Gijón performing a gymnastic exhibition. Source: Noticiario n. ${ }^{\circ} 853 \mathrm{~A}(11 / 05 / 1959)$.

The LUs had classrooms, housing for apprentices, workshops, sports fields (see Image 6), a dining hall, rest and study rooms and other facilities "appropriate to the size of this project" (Noticiario n. ${ }^{\circ} 526 \mathrm{~A}, 02 / 02 / 1953$ ). It is evident that the size and layout of these buildings were made to convey emotions, to impress; chapels, halls, theatres, courtyards were spectacular, impressive. In short, huge and magnificent buildings that, in addition to housing impressive workshops, machinery and facilities (Delgado-Granados and Ramírez Macías, 2017), conveyed the feeling of grandeur, of power, where the future worker could feel small in this macro-institution (see Image 7), but at the same time each they could feel part of the "Francoist revolutionary action in favor of the Spanish, and in which the worker would be" the active subject of the entire social revolution "(Delgado-Granados and Ramírez Macías, 2017, p. 128 ). Currently, most of these buildings have been restored and host educational or cultural institutions (image 8). 


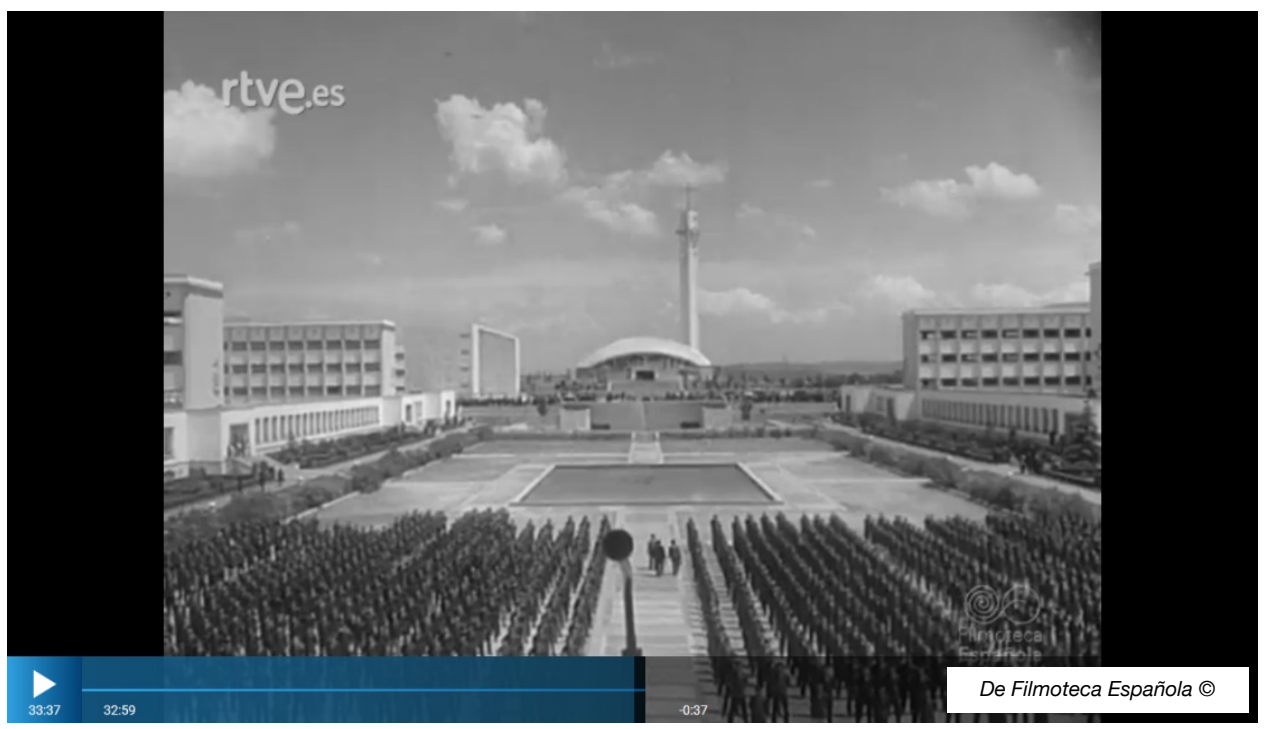

Image 7: Students from the Onésimo Redondo Labor University (Córdoba) lining up to receive Franco. Source: Noticiario n. ${ }^{\circ} 958$ A (15/05/1961).
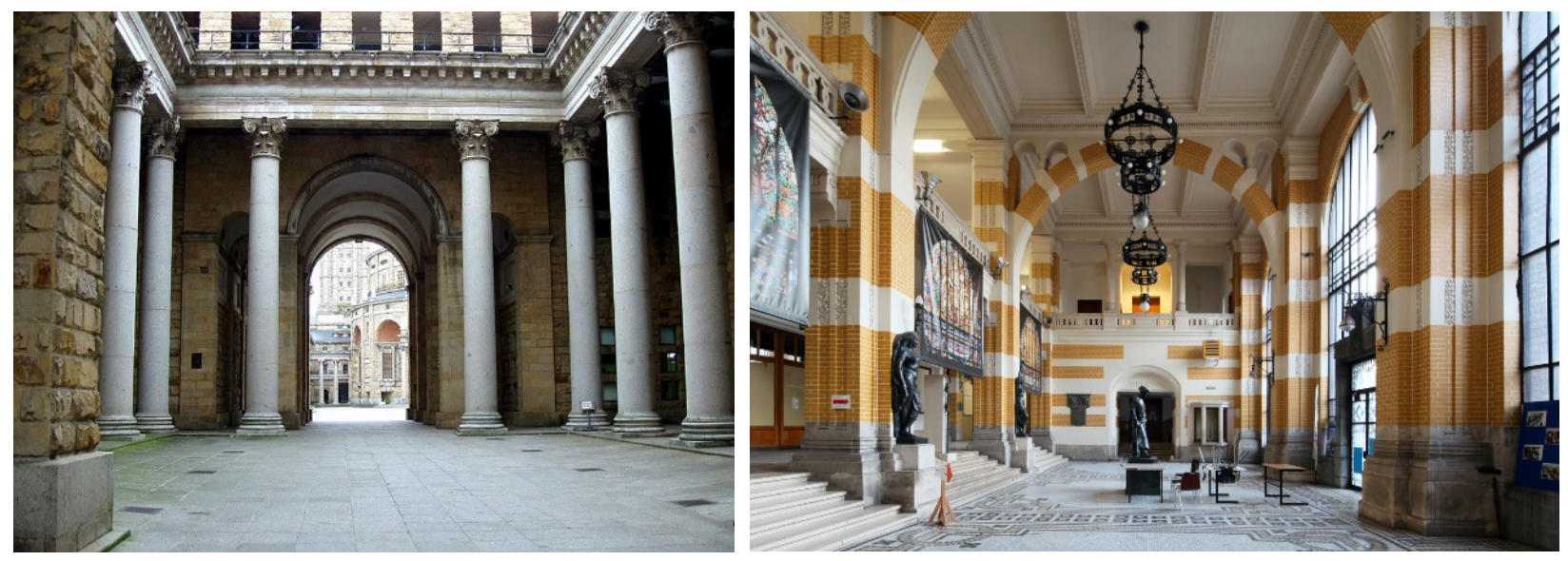

Image 8: Corinthian courtyard at the entrance to the Labor University in Gijón and Entrance Hall, building Gramme, Université du Travail. Source: Images retrieved from https://mapio.net/pic/p-2584311/ and https://upload.wikimedia.org/wikipedia/commons/4/40/Universit\%C3\%A9-du-travail-paul-pasturcharleroi-gramme-hall-maxime-delvaux-2.JPG.

\section{Conclusions}

Labor Universities were created by José Antonio Girón who took the Belgian Labor University founded by Paul Pastur in Charleroi (Belgium) as a reference. The two projects had similarities, but also differed in other respects, the most notable being the context situation they came from and the context into which they were implemented. The first similarity is the name of both institutions, since the Spanish name was an almost literal translation of the Belgian one, although in both cases the degree they offered was not a university but an intermediate one. Another similarity is that the goal 
of both organizations was the technical and cultural training of the working class, providing them with the possibility of accessing studies that were up-to-then off-limits. In order to access these courses with a scholarship, students had to pass, in the case of Spain, a series of tests. These studies not only trained young men for a job, but also provided them with a manual training and a cultural level that would allow them to integrate into society.

The Labor Universities in Spain and the Belgian Labor University were founded by two lawyers with an interest in the workers' cause, especially the working conditions of the miners, although they came from different ideological backgrounds: Girón was a prominent Falangist and Francoist and Pastur was a Mason who was involved in the workers' movement as leader of the Belgian Workers' Party and was a permanent socialist deputy in Hainaut from June 1900 until his death.

Both institutions took great care in the architecture and design of the spaces where they set themselves up: large buildings with spacious workshops, classrooms, laboratories, dining rooms, rest and study rooms where the students could be accommodated. The courses on offer focused on training students in different skills such as lathing, trimming, carpentry, foundry, automobile, metal, welding, electricity, etc. Spanish Labor Universities also taught agricultural and maritime-fishing subjects. Students were mostly males, although at the UT there was a subject aimed at women.

The main difference between the Belgian Labor University and the Spanish Labor Universities was the context in which they were set up. The region where Paul Pastur founded the Labor University was one of the most industrially developed. It was the workers' revolutions of 1886 that revealed the discontent of the workers living in poor conditions, so Pastur took action and adopted a series of social measures to try to alleviate this situation. The nature of this Labor University was distinctively socialist and secular and its mission was to give workers an all-round training in order to "raise the educational and intellectual standard to the level of the best elites" and thus respond to the "aspirations of the workers and small businessmen" and feed the "industry with qualified technical workers" (Delgado Granados, 2010, pp. 90-91). However, Spanish Labor Universities were founded in a strong totalitarian and Catholic context. Apart from trying to raise the cultural level of the workers and to provide them with technical training to which they would otherwise have no access, they sought to indoctrinate the working classes in the principles of National Unionism and Catholicism, to perpetuate the doctrine of the new regime and, in this way, prevent revolutions. The fact that they were conceived as a boarding school reinforced that mission. The opening speech for the 1971-1972 academic year read by Licinio de la Fuente at the Labor University of Gijón still reflected the idiosyncrasies of these institutions even in the final years of the regime:

The Labor University is a learning centre. But it is also -and I dare say that it is above all- a service of social advancement, since its reason for being, its title of 
legitimacy, was and is that of providing and guaranteeing to the workers access to knowledge and, with it, their participation in the political development, in the economic development and in the social development (as cited in Delgado Granados, 2005a, p. 248).

In our country, up to twenty-five Labor Universities were founded, which were closed down in 1983 when it became clear that they were extremely expensive institutions and that what they offered overlapped with what was provided by other public institutions following the General Education Act passed in 1970. Most of the Spanish Labor University buildings have now different educational or cultural uses. The Belgian Labor University is still in operation, having adapted to new educational legislation and new training needs.

\section{Notes}

1. Documentaries were one of the regular activities NO-DO kept throughout its existence, as the founding Regulation (29/09/1942) specified that NO-DO should make documentaries, even though they did not have the status and, as they had to coexist with private documentary production, they were not compulsory as newsreels were. The Black and White Documentary section was first released in 1943, although its production did not begin to increase until the 1950s, reaching its peak in the 1960s. In total, 216 releases were produced in this section. Color Documentaries were first released in 1949, although their production stopped and did resumed until 1954, reaching its production peak starting from 1969. In total, 495 releases were produced. 2. The Image Magazine was first published in January 1945 and kept on going until 1968. It was a weekly publication and is considered the most important magazine produced by NO-DO. The duration of the films was around ten minutes and the summary was made up of several reports (national or foreign that were not topical, so it did not matter that they were old news in terms of the production of the magazine) grouped around a common theme. A total of 1228 black and white films were screened and, as with the documentaries, the screening of the Image Magazine was not compulsory.

3. The observation form includes the following sections: the NO-DO section comprising of news, documentary or report (News, Black and White Documentary, Color Documentary, Image Magazine and Images of Sport); number and date of the film's release; minute at which the educational scene appears; name of the institution and location where the scene takes place; description of everything that happens in the educational scene; and narration.

4. Except for the University of Tarragona, which was run by laymen, the LUs of Gijón, Córdoba, Seville and Zamora were managed by the Jesuits, the Dominican Order and 
the Salesians (Seville and Zamora), respectively. In addition, it was decided that the patron of these centers would be Saint Joseph and that every year "Labor Day would be celebrated in all Labor Universities, with religious, academic and sports events" (Robles Cardona, 2014, p. 60).

5. The Vocational Training School of the San José Foundation and José Antonio Girón in Zamora was classified in 1959 as a private charity-teaching entity. In 1960 it was integrated into the system of LUs under the name of San José Labor University.

\section{References}

Bascuñán, J. (1999). A cada uno su oficio... Educación y promoción profesional. In A. Mayordomo (Coord.), Estudios sobre política educativa durante el Franquismo (pp. 223-226). Valencia: Universitat de Valencia.

Brunet i lcart, I., \& Moral Martín, D. (2017). Origen, contexto, evolución y futuro de la Formación Profesional. Tarragona: URV.

Cenarro Lagunas, A. (2005). La sonrisa de la Falange. Auxilio social en la guerra civil y en la posguerra. Barcelona: Crítica.

Cenarro Lagunas, A. (2009). Los niños del auxilio social. Madrid: Espasa.

Chan, M. K., \& Dirlik, A. (1991). Schools into Fields and Factories: Anarchists, the Guomindang, and the National Labor University in Shanghai, 1927-1932. Durham and London: Duke University Press.

Decreto 2265/1960, de 24 de noviembre, por el que se aprueba el Reglamento orgánico de las Universidades Laborales. Boletín Oficial del Estado, 6 de diciembre de 1960, núm. 292, 16749-16760. Retrieved from https://www.boe.es/boe/dias/ 1960/12/06/pdfs/A16749-16760.pdf

Delgado Granados, P. (2005a). La universidad de los pobres: historia de la Universidad Laboral sevillana y su legado a la ciudad. Sevilla: Universidad de Sevilla.

Delgado Granados, P. (2005b). El profesorado de las Universidades Laborales y su práctica escolar. El Guiniguada, (14), 61-74. Retrieved from https://accedacris. ulpgc.es/bitstream/10553/5778/1/0235347_00014_0005.pdf

Delgado Granados, P. (2010). El proyecto de Universidad gironiano para la clase trabajadora y su sistema de estudios. Sarmiento: Anuario galego de historia da educación, (14), 89-107. Retrieved from https://ruc.udc.es/dspace/bitstream/ handle/2183/8471/SAR\%2014\%202010\%20art\%207.pdf?sequence=1

Delgado Granados, P. (2012). Formación profesional, educación y trabajo: retrospectiva de las Universidades Laborales. Madrid: Biblioteca Nueva.

Delgado-Granados, P., \& Ramírez-Macías, G. (2017). ¿Conveniencia o necesidad? La formación de la clase obrera en las Universidades Laborales franquistas (19551978). Historia Crítica, (63), 117-136. doi: https://doi.org/10.7440/histcrit63.2017.06 
Díaz González, M. M. (2017). La Universidad Laboral de Gijón (Asturias). El primer gran proyecto filantrópico gironiano al servicio de la patria: 1945-1978. Hispania Nova: Revista de historia contemporánea, (15), 191-216. Retrieved from https://e-revistas. uc3m.es/index.php/HISPNOV/article/view/3486/2122

Dueñas Cepeda, M. J. (2010). La construcción de las relaciones de género en la ideología de la Sección Femenina, 1934-1977. In L. Prieto Borrego (Ed.), Encuadramiento femenino, socialización y cultura en el Franquismo (pp. 23-73). Málaga: Centro de Ediciones de la Diputación de Málaga.

García Delgado, J. L. (2003). La economía de la España democrática: un ejercicio de interpretación. CIRIEC - España. Revista de economía pública, social y cooperativa, (47), 149-157.

García Delgado, J. L., \& Jiménez, J. C. (2007). Segunda parte. La economía. In S. Juliá, J. L. García Delgado, J. C. Jiménez \& J. P. Fusi (Coords.), La España del siglo XX (pp. 331-527). Madrid: Marcial Pons Historia.

González de Tena, F. (2009). Niños invisibles en el cuarto oscuro: experiencias en el auxilio social del franquismo. Madrid: Editorial Tébar.

Ley de 16 de julio de 1949 de Bases de Enseñanza Media y Profesional. Boletín Oficial del Estado, 17 de julio de 1949, núm. 198, 3164-3166. Retrieved from https://www. boe.es/datos/pdfs/BOE/1949/198/A03163-03164.pdf

Ley de 20 de julio de 1955 sobre "Formación Profesional Industrial". Boletín Oficial del Estado, 21 de julio de 1955, núm. 202, 4442-4453. Retrieved from https://www.boe. es/datos/pdfs/BOE//1955/202/A04442-04453.pdf

Ley 40/1959, de 11 de mayo, sobre Universidades Laborales. Boletín Oficial del Estado, 12 de mayo de 1959, núm. 113, 6929-6930. Recuperado de: https://www. boe.es/buscar/doc.php?id=BOE-A-1959-6707

Martín de la Guardia, R. (2006). Los medios de comunicación social como formas de persuasión durante el primer franquismo. In J. M. Delgado Idarreta (Coord.), Propaganda y medios de comunicación en el primer franquismo (1936-1959) (pp. 15-28). La Rioja: Universidad de La Rioja.

Martínez Usarralde, M. J. (2002). Historia de la formación profesional en España: de la Ley de 1955 a los Programas nacionales de formación profesional. Valencia: Servei de Publicacions, Universitat de València.

Martínez Usarralde, M. J. (2015). Consideraciones a una ley paradigmática en la Historia de la Formación Profesional española: la Ley de Formación Profesional Industrial (FPI) de 1955. Participación Educativa, 4(6), 107-112. Retrieved from https://sede.educacion.gob.es/publiventa/detalle.action?cod=20422

Morant i Ariño, A. (2013). Mujeres para una "Nueva Europa": las relaciones y visitas entre la Sección Femenina de Falange y las organizaciones femeninas nazis. Doctoral dissertation. Universitat de València, España. Retrieved from http://roderic. uv.es/handle/10550/32256 
Paz, M. A. (2003). The Spanish Remember: movie attendance during the Franco dictatorship, 1943-1975. Historical Journal of Film, Radio and Television, 23(4), 357374.

Robles Cardona, M. A. (2014). La arquitectura de las Universidades Laborales españolas (1946-1978). Doctoral dissertation. Universitat Politècnica de Catalunya (UPC), España. Retrieved from https://www.tdx.cat/handle/10803/279311

Rodríguez Martínez, S. (1999). El NO-DO: catecismo social de una época. Madrid: Editorial Complutense.

Rodríguez Mateos, A. (2008). Un franquismo de cine: la imagen política del régimen en el noticiario NO-DO (1943-1959). Madrid: Rialp.

Sánchez-Biosca, V. (2009). NO-DO y las celadas del documento audiovisual. Cahiers de civilisation espagnole contemporaine, (4), 1-7. Retrieved from http://roderic.uv. es/bitstream/handle/10550/29172/059791. pdf?sequence=1\&isAllowed=y

Sánchez Sánchez, G. (2006). La Universidad Laboral de Zamora: una manifestación del proyecto social y educativo del franquismo (1946-1980). Zamora: Instituto de Estudios Zamoranos "Florián de Ocampo".

Sevillano Calero, F. (1998). Propaganda y medios de comunicación en el franquismo (1936-1951). Alicante: Publicaciones de la Universidad de Alicante. Retrieved from https://rua.ua.es/dspace/bitstream/10045/33149/1/Sevillano_Calero_Propaganda_ medios.pdf

Sevillano Calero, F. (2000). Ecos de papel. La opinión de los españoles en la época de Franco. Madrid: Biblioteca Nueva.

Soriano, J. (1942). Se crea NO-DO. Primer Plano, (115), 7.

V.AA. (2011). Charleroi 1911-2011. L'industrie s'associe à la culture. Charleroi: Ville de Charleroi.

Velasco Mesa, C. (2004). Acerca de la industrialización del eje Sambre-Mosa y de las agitaciones obreras de 1886 en Bélgica. Huelva en su historia, (11), 203-226. Retrieved from http://rabida.uhu.es/dspace/bitstream/handle/10272/3137/b1514 1603.pdf?sequence $=1$

Zafrilla Tobarra, R. (1999). Universidades Laborales: un modelo de educación falangista en el franquismo. In J. Ruiz Berrio, A. Bernat Montesinos, M. R. Domínguez Cabrejas \& V. M. Juan Borroy (Coords.), La Educación en España a examen (1898-1998): jornadas nacionales en conmemoración del centenario del noventayocho (vol. 2) (pp. 177-184). Zaragoza: Ministerio de Educación y Cultura; Instituto "Fernando El Católico"; Diputación de Zaragoza.

Yllán Calderón, E. (2016). El franquismo. Madrid: Ediciones AKAL. 